\title{
The Development of Students' Independence in The Conditions of Distance Learning
}

\author{
Svetlana Nikolaevna Vahrusheva $^{1^{*}}$, Tatyana Viktorovna Masharova $^{2}$, and Veranika \\ Punchyk $^{3}$ \\ ${ }^{1}$ The Institute (Branch) of the O. E. Kutafin Moscow State Law Academy in Kirov, Kirov, Russia \\ ${ }^{1}$ Moscow City University, Moscow, Russia \\ ${ }^{3}$ Belarusian State Pedagogical University named after Maxim Tank, Minsk, Belarus
}

\begin{abstract}
This article presents the authors' studies on the development of students' independence in the conditions of distance learning. The purpose of the study is to compare the results of the development of students' independence in the format of distance education for different categories of students. The main methods of work are questionnaires of teachers of secondary schools of the Kirov region and statistical analysis of the results obtained. The study found that distance learning differently affects learners based on age and subject. Thus, high school students show better results compared to primary school students and basic general education. In this regard, humanities are preferable to natural science subjects.
\end{abstract}

\section{Introduction}

Describing human abilities, one of the most important components is independence. Different interpretations of the term can be found in pedagogy and psychology. "Independence as a stable quality of personality provides a high level of success and practical feasibility of plans and intentions in any activity" [1].

In our understanding, autonomy is a multidimensional personal education, which is formed in needs and manifests itself in activities, skills of the learner to set themselves goals, formulate significant problems for themselves, choose the means to solve them, persevering to achieve positive results, give self-assessment of activities [2, 3].

For example, L. V. Zharova justifiably believes that independence is the result of education and self-education [4]. It is the most important condition for the self-realization of the individual and creative abilities.

How to strengthen the formative effect? One possible option of pedagogical accompaniment is the transition from the pedagogical support model to pedagogical assistance. That is, from "contact" cooperation to "remote" independence, to a kind of form of informal education [5-7].

The most important components of independence include:

* Corresponding author: vahrusheva8svetlana@mail.ru 
- general training skills (reading the text correctly, finding the answer to the question, drawing up the plan of the read, theses, outline, tables, planning your activities, controlling the actions performed);

- general logical skills: (identifying the essentials, making comparisons, proving, drawing conclusions, formulating questions);

- Subject (special) skills, reflecting the specifics of individual educational disciplines);

- meta-subject skills (universal training actions);

- communication skills (conduct dialogue, participate in joint activities).

Do learners with knowledge and skills always seek to be independent? To do this, they often need a motivational setup that sets in motion knowledge and skill, prompts to action without assistance, without reminding. However, there is also a need for a conation to make an independent decision. Scientists identify three main constituent parts of independence: skill, motive, will. They are interrelated and interdependent [8].

Underestimation of practical independence leads to the fact that students do not know how to use the knowledge gained in difficult life situations, do not know how to set goals and achieve them, plan and establish interaction [4].

Therefore, teachers should not only be proficient in the knowledge and skills provided by the chosen profession but also independently improve the applicative knowledge by applying them in practice, to work competently with information, to devote time to self-education [9, $10]$.

The teacher is faced with the task of developing several qualities among students, such as self-organization, self-control, independence, initiative, to develop skills in planning and performing educational and cognitive activities. Achieving the goals is impossible without properly organized independent work. Much attention is paid in this regard to the formation of independent thinking.

A specialist needs to learn almost all life in modern society, with rapid information growth. It used to be possible to afford to learn once and for all [11]. Today, the idea of continuous "lifelong" education leads to the need to find new methods of transferring knowledge and learning technologies. One such technology is distance learning.

Beginning in the 20th century, distance education, which claims to have a special form of education (along with full-time, part-time, evening, external studies), occurs with the motto "education for all" at any distance, occupying an increasingly important role in the modernization of education.

What is the essence of this form of education? According to the law "On Education in the Russian Federation," it is a complex of technologies by which students are provided with a certain amount of study material based on the interactive interaction of students and teachers in the process of learning, providing students with the possibility of independent work which is very important — on the mastering of the material studied. The learners receive the material intended for mastering and learn it independently at a convenient time for them. During the conference, they communicate with the teacher online, e-mail, or Skype, ask questions, can get advice on a misunderstood section, and send assignments. Later, the teacher evaluates the learner's knowledge [12].

Remote learning, implemented with the help of computer telecommunications, on the Internet, e-mail has the following forms of classes. Chat classes are training sessions conducted with the use of chat technologies. Chat classes are conducted synchronously, meaning all participants have simultaneous access to the chat. Web classes - distance lessons, conferences, seminars. Web forums differ from chat sessions by the possibility of longer (multi-day) work and the asynchronous nature of the interaction between students and teachers. Teleconferencing - usually conducted based on e-mail mailing lists. Educational teleconferencing is characterized by the achievement of specific educational tasks. Also, there are forms of distance learning in which educational materials are sent by mail. 


\section{Methods}

The introduction of the self-isolation regime throughout Russia, including in the Kirov region, due to the spread of coronavirus disease prompted the active development of the remote form training. It is probably appropriate here to say, "If it weren't for bad luck have no luck at all." Surely, after gaining thorny experience for many people, such training will be more actively included in the educational process.

The main method of research on the influence of distance learning on the development of students' independence was the questionnaire of teachers of the Kirov region working in conditions of self-isolation. Four general educational organizations of the region participated in the study. This is the Kirov Regional State Educational Budgetary Institution "Secondary school with an in-depth study of individual subjects of the Bogorodskoye village", deputy principal - Chetverikova Svetlana Vladimirovna. Municipal budgetary general education institution "Secondary comprehensive school with in-depth study of individual subjects No. 2 of Kotelnich", deputy principal - Tsybaeva Elena Alexeevna. Kirov Oblast State Educational Budgetary Institution "Orlov Secondary School", deputy principal - Korotaeva Marina Evgenievna. Municipal budgetary educational institution "Secondary school with indepth study of individual subjects No. 66" of the city of Kirov, deputy principal - Skurikhina Julia Alexandrovna.

At first, on-line meetings were held with the teachers of the above schools, at which the goals and objectives of the experiment, the methodology of filling out the table of the proposed questionnaire compiled by the authors were explained. At the end of the survey, a second meeting was held, where questionnaires were analyzed and the overall results were summarized $[13,14]$.

\section{Results}

As the results of the study of students' independence in the conditions of distance learning, we gave a generalized table of teachers' answers to the main question of the questionnaire: how did distance learning affect the development of the independence of your students? In particular, on the formation of functional literacy? In the cells, specify the number of teachers who responded (as a percentage of the total number of those who responded in this category). "Applied sciences" in our questionnaire include physical education, world art culture, and technology.

Table 1: Influence of distance learning on the development of students' independence

\begin{tabular}{|l|l|l|l|l|l|}
\hline Age & & Yes & No & $\begin{array}{l}\text { Don't } \\
\text { know }\end{array}$ & No answer \\
\hline Primary School & All subjects & 12 & 77 & 11 & \\
\hline \multirow{3}{*}{ Main School } & Exact sciences & 25 & 44 & 18 & 13 \\
\cline { 2 - 7 } & Humanities & 57 & 34 & & 9 \\
\cline { 2 - 7 } & Applied & 24 & 17 & 27 & 32 \\
\hline \multirow{3}{*}{ High School } & Exact sciences & 46 & 34 & 5 & 15 \\
\cline { 2 - 7 } & Humanities & 88 & 7 & 3 & 2 \\
\cline { 2 - 6 } & Applied & 37 & 24 & 16 & 23 \\
\hline
\end{tabular}

Answers to the second question of the questionnaire: What problems were detected in the organization of distance learning? (Total, in sum - 100\%), placed as follows:

- technical (lack of equipment for practical, research, observation) $68 \%$,

- organizational (interaction with administration, parents, teachers, students) 13\%,

- methodical (method of individual training) 9\%, 
- information (availability of computers, Internet networks) 10\%.

\section{Discussion}

The study showed that in the conditions of self-isolation when learning was forced to switch to remote mode, the process of formation of students' independence goes differently.

1. It is the most successful and effective for high school students. At this age, students already know how to work independently, attracting the necessary information sources.

2. Primary students found themselves in a more difficult situation. Many of them still require constant assistance from teachers (contact pedagogical support).

3. A better position is taken by the humanities. The answers to many questions here are quite freely formulated, so students can be more self-reliant than in exact subjects. Also, it is necessary to conduct experiments in chemistry, physics, biology, which is very difficult to do on its own.

4. Compared to urban schools, schools in rural areas show worse results for technical reasons (Internet speed and availability, computer availability) and social (limited interaction, lower educational level of parents) [15].

\section{Conclusion}

In the 21 st century, the availability of computers and the Internet greatly facilitates the spread of distance learning. The ability to communicate and receive feedback from any student found a wide response in the educational sphere. This is caused by several undeniable advantages.

Thus, the use of modern software technologies allows making the learning process more efficient, since the learner, having received the task electronically, has to think and decide independently how to perform it. He/she can no longer immediately get the teacher's answer to the question and will try to be active and find the right way out. This approach contributes to the development of independence as a quality of personality, without which the future specialist will not be able to work fruitfully, creatively.

The emotional factor should not be forgotten either. The nervousness of both the teacher and the learner decreases in the conditions of distance learning. The psychological impact is reduced, the excitement and fear that the child sometimes experiences during classwork disappear, being afraid to give the wrong answer. However, along with the advantages, getting distance education is also problematic [16].

The problems include the following features: there is no direct communication between the teacher and the learner, emotional relationship in interaction. Learning does not take place in the classroom, so some students in the absence of such an incentive as the manifestation of their individuality in front of their fellow students lose their interest in learning activities, creative independence [17].

Strict self-discipline is necessary for this training format, which depends directly on independence and self-awareness. Our students are used to constant control from the teacher, and this is a powerful incentive. The role of direct contact with the teacher is still high. Preparation for classes takes the teacher a lot of time. We have to think through every moment when preparing tasks for methods and techniques that will not cause particular difficulties for students, will not reduce interest but will encourage them to become independent in preparation $[18,19]$.

Thus, distance learning is new in school and everything new is interesting. We are not ready to replace traditional education with distance learning completely, but it can serve as a good addition to the generally accepted and familiar one. 


\section{References}

1. I.K. Kondaurova, Organization of independent cognitive activity of junior students (Publishing House of Ped. in-te, Saratov, 1999)

2. S.N. Vakhrusheva, Development of cognitive independence of students in teaching a foreign language in a non-linguistic university (Izd-vo MCITO, Kirov, 2000)

3. P.I. Pidkasisty, Independent activity of students in learning (MGPI, Moscow, 1978)

4. L.V. Zharova, To teach independence: a book for the teacher (Education, Moscow, 1993)

5. A. Grajcevci, Action Researcher in Education 7, 119 -130 (2016)

6. J. Quinn, Policy Futures in Education 16(2), 144-155 (2017)

7. M. Souto-Otero, Validation of Non-Formal and Informal Learning in Europe: Research, Policies, Legitimacy and Survival, in S. Bohlinger, K. Dang, G. Klatt (eds) Education Policy: Mapping the Landscape and Scope (Peter Lang. P., Frankfurt, 2016)

8. L.G. Vyatkin, The formation of internal learning incentives for students: collection of scientific works (Saratov State University, Saratov, 1991)

9. D. Jansen, L. Konings, The 2018 OpenupEd Trend Report on MOOCs (European Association of Distance Teaching Universities, Maastricht, 2018). Available at: https://www.openuped.eu/images/Publications/The 2018_OpenupEd trend_report_on MOOCs.pdf

10. M. Singh, R. Duvekot, Linking Recognition Practices and National Qualifications Frameworks, (UNESCO Institute for Lifelong Learning, Hamburg, 2013)

11. F. Villar, M. Celdrán, European Journal Ageing 10(2), 135-144 (2013)

12. Federal Law No. 273 "On Education in the Russian Federation" (December 29, 2012) Available at: https://rg.ru/2012/12/30/obrazovanie-dok.html

13. E. Hanushek, M. Piopiunik, S. Wiederhold, Education Next 2, 57-64 (2019)

14. A. Hargreaves, M. Fullan, Professional Capital: Transforming Teaching in Every School, (Teachers College, New York, 2015)

15. P.L. Morgan, G. Farkas, M.M. Hillemeier, S. Maczuga, Educational Researcher 45(1), 18-35 (2016)

16. R. Garrison, International Review of Research in Open and Distance Learning 1(1), 315 (2000)

17. R.J. Skiba, C.G. Chung, M. Trachok, T.L. Baker, A. Sheya, R.L. Hughes, American Educational Research Journal 51(4), 640-670 (2014)

18. T.V. Masharova, Educational activity as a factor in the social self-determination of a teenager (Izd-vo MCITO, Kirov, 2000)

19. M. Moore, Journal of Higher Education 44(12), 661-679 (1973) 